\title{
Cowpea yield on soils with residues of NPK and natural phosphate fertilizers in succession the area of degraded pasture ${ }^{1}$
}

\author{
Pedro Emerson Gazel Teixeira ${ }^{2}$, Antonio Rodrigues Fernandes ${ }^{2}$, Jessivaldo Rodrigues Galvão ${ }^{2 *}$, \\ Wendel Valter da Silveira Pereira ${ }^{2}$, Sandro Rogério Almeida Casanova ${ }^{2}$, Pedro Paulo da Costa Alves Filho ${ }^{2}$
}

$10.1590 / 0034-737 X 201663040017$

\begin{abstract}
The cultivation of cowpea [Vigna unguiculata (L) Walp] can be an important alternative in succession to maize in areas of degraded pastures due to the use of residue from fertilizers. With this, we aimed to evaluate the productivity of cowpea as a successor culture to undergo corn doses of reactive natural phosphate Arad and combinations with NPK. The experimental design was a randomized block design in a split plot with four replications. The fertilizer was applied in previous cultivation (crop) using four phosphate doses in the form of Arad natural phosphate: 50, 100, 200 and $300 \mathrm{~kg}$ $\mathrm{ha}^{-1}$ of $\mathrm{P}_{2} \mathrm{O}_{5}$ and the sub-plots in combination with NPK, NK, NK + liming, and control (no liming and fertilizer). The cowpea yield components were evaluated in this work. The residues of $\mathrm{P}_{2} \mathrm{O}_{5}$ from the natural phosphate increased the phosphorus content in the plant and influenced the number of grains per pod. The residual effect of NK+ liming and only NK showed better results for the variables grain yield, number of pods per plant, number of seeds per pod and dry mass of aerial part. The residual effect of NPK showed better results for the mass of 100 grains.
\end{abstract}

Key words: Arad phosphate; liming; soluble phosphate; Vigna unguiculata.

\section{RESUMO}

\section{Rendimento de feijão-caupi em solos com resíduos de NPK e fertilizantes fosfatados naturais em sucessão a área de pastagem degradada}

O cultivo do feijão caupi [Vigna unguiculata (L) Walp] pode ser uma alternativa importante em sucessão ao cultivo do milho em áreas de pastagens degradas, devido ao aproveitamento do resíduo das adubações. Com isto, objetivou-se avaliar a produtividade do feijão-caupi como cultura sucessora ao milho submetido a doses de fosfato natural reativo de Arad e combinações com NPK. O experimento foi conduzido no município de Santo Antônio do Tauá, estado do Pará, em área de pastagem degradada, onde o solo foi classificado como Latossolo Amarelo Distrófico. O delineamento experimental foi blocos ao acaso em parcelas subdivididas, com quatro repetições. A adubação foi realizada na cultura anterior (milho) utilizando-se, nas parcelas, quatro doses de fósforo na forma de fosfato natural de Arad: 50, 100, 200 e $300 \mathrm{~kg} \mathrm{ha}^{-}$ ${ }^{1}$ de $\mathrm{P}_{2} \mathrm{O}_{5}$ e as subparcelas a combinação com NPK, NK, NK + calagem, e o controle (sem calagem e adubação). Avaliaramse os componentes de produtividade da cultura do feijão-caupi. Os resíduos das doses de $\mathrm{P}_{2} \mathrm{O}_{5}$, proveniente do fosfato natural elevaram a concentração de fósforo na planta e influenciaram no número de grãos por vagem. $\mathrm{O}$ efeito residual dos fertilizantes NK + calcário e somente NK apresentaram melhores resultados tratando-se de produtividade de grãos, número de vagens por planta, número de grãos por vagem e massa seca da parte aérea. Os resíduos da aplicação de NPK apresentaram melhor resultado para a massa de 100 grãos.

Palavras chave: calagem; fosfato de Arad; fosfato solúvel; Vigna unguiculata.

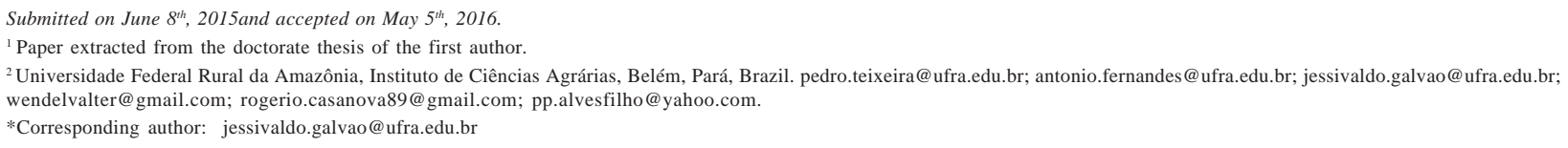




\section{INTRODUCTION}

The cultivation of cowpea [Vigna unguiculata (L) Walp] can be an important alternative in succession to maize in areas of degraded pastures due to the use of residue from fertilizers. These areas are usually abandoned by farmers and left outside the farming process, leading to deforestation of new areas of native forests (Neves Junior et al., 2013). Alternatives must be sought for the recovery and the reform of pasture in relation to the incorporation of new areas through the traditional process of forest cutting and burning for economic and environmental issues (Costa et al., 2013).

The availability of phosphorus in the soils is influenced by a series of chemical reactions, especially adsorption. The soluble phosphates provide more rapidly the element for plants, however, they adsorb more strongly in the soil than the reactive phosphate which, in turn, provides a longer lasting residual effect despite their slow and gradual solubilization (Freitas et al., 2009). In highly weathered soils of the humid tropics, this element is considered the most limiting nutrient for plant productivity due to its low availability (Novais et al., 2007).

Phosphorus has been often supplied in the form of soluble phosphate at sowing. However, the use of residual power of lower cost alternative sources such as natural reactive phosphate can be an efficient management practice in sequential crop/livestock integration systems. The average yield of cowpea beans in the state of Pará reaches $720 \mathrm{~kg} \mathrm{ha}^{-1}$ according to the Secretaria de Agricultura do Pará (2013), but crops of BRS-Guariba cultivar, in which technologies such as fertilization are used, have reached 1,590 and 2,211 $\mathrm{kg} \mathrm{ha}^{-1}$ (Galvão et al., 2013; Teixeira et al., 2010), with the expectation to reach or exceed $3,000 \mathrm{~kg} \mathrm{ha}^{-1}$.

The chemical fertilization and liming used in the middle region of northeastern Pará are generally inadequately carried out. In a survey conducted in the region, Carvalho et al. (2002) found that farmers who use fertilizer applications do not use the most efficient formulations for each case, often because of lack of scientific information,

Thus, it is necessary to explore ways to develop continuous and sustainable systems of soil management, including bringing back to the farming process the altered areas, now marginalized. Thus, the objective of this study was to evaluate the residual power of Arad reactive phosphate and the combination with fertilizers on the productivity of cowpea crop in recovered areas.

\section{MATERIAL AND METHODS}

The experiment was carried out in the municipality of Santo Antônio do Tauá ( $1^{\circ} 03^{\prime} 58^{\prime \prime S}$ and 4803'26"W, $27 \mathrm{~m}$ above sea level), in the northeast of Pará state from January
2007 to December 2008. The soil was classified as dystrophic Yellow Latosol (Embrapa, 2006). According to the Köppen classification, the prevailing climate in the region is Afi with an average annual temperature of $26^{\circ} \mathrm{C}$, and annual average rainfall of 2,604 $\mathrm{mm}$.

The area was initially not used for 15 years, previously used to pasture, where cutting down of trees and burning had been carried out with no application of fertilizers and soil correction, which contributed to degradation.

Before setting up the first experiment (corn), soil samples were collected from the 0.0 to $0.2 \mathrm{~m}$ layer, whose chemical and physical analyses (Embrapa, 1997) resulted into: $\mathrm{pH}(\mathrm{KCl})=4.8 ; \mathrm{P}=2.7 \mathrm{mg} \mathrm{dm}^{-3} ; \mathrm{K}^{+}=0.04 \mathrm{cmol}_{\mathrm{c}} \mathrm{dm}^{-3}$, $\mathrm{Ca}^{++}=0.23 \mathrm{cmol}_{\mathrm{c}} \mathrm{dm}^{-3} ; \mathrm{Mg}^{++}=0.23 \mathrm{cmol}_{\mathrm{c}} \mathrm{dm}^{-3} ; \mathrm{V} \%=8.9$; aluminum saturation $(\mathrm{m} \%)=66 ; \mathrm{Al}^{+++}=1.0 \mathrm{cmol}_{\mathrm{c}} \mathrm{dm}^{-3} ; \mathrm{OM}$ $=15.94 \mathrm{~g} \mathrm{~kg}^{-1}$; fine sand $=462 \mathrm{~g} \mathrm{~kg}^{-1}$; coarse sand $=351 \mathrm{~g}$ $\mathrm{kg}^{-1}$; silt $=177 \mathrm{~g} \mathrm{~kg}^{-1}$; and clay $=100 \mathrm{~g} \mathrm{~kg}^{-1}$. Contents of $\mathrm{P}$ were extracted by Mehlich $1\left(0.0125 \mathrm{~mol} \mathrm{~L}^{-1}\right.$ of $\mathrm{H}_{2} \mathrm{SO}_{4}+0.05$ $\mathrm{mol} \mathrm{L}{ }^{-1}$ of $\mathrm{HCl}$ ).

This work used a random block experimental design a split plot design with four replications, where each plot measured $84 \mathrm{~m}^{2}$ and the subplots had $21 \mathrm{~m}^{2}$. In the previous crop (corn), four doses of phosphorus were applied into the plots: 50, 100, 200 and $300 \mathrm{~kg} \mathrm{ha}^{-1}$ of $\mathrm{P}_{2} \mathrm{O}_{5}$ in the form of Arad natural reactive phosphate $\left(30 \% \mathrm{P}_{2} \mathrm{O}_{5}\right.$ soluble in citric acid) and combination with NPK $\left(50 \mathrm{~kg} \mathrm{~N}+60 \mathrm{~kg}\right.$ of $\mathrm{P}_{2} \mathrm{O}_{5}$ $\left.\mathrm{ha}^{-1}+51 \mathrm{~kg} \mathrm{ha}^{-1} \mathrm{~K}_{2} \mathrm{O}\right)$, NK (111 kg ha-1 urea $+84 \mathrm{~kg} \mathrm{ha}^{-1}$ of potassium chloride), $\mathrm{NK}+\operatorname{liming}\left(111 \mathrm{~kg} \mathrm{ha}^{-1}\right.$ of urea +84 $\mathrm{kg} \mathrm{ha}^{-1}$ potassium chloride + liming) and control (no NK and no liming). The lime used in the experiment presented PRNT of $77 \%$, in which 2.59 tha $^{-1}$ were applied, calculated by the exchangeable aluminum method. Cultivar BRS 106 corn was used as indicator plant.

The area was tilled using mechanized removal of the existing vegetation (shrubs) and then plowing followed by light harrowing. Lime was applied with mechanical distributor and incorporated into the soil by harrowing, 90 days before planting. Arad natural phosphate was applied at a single dose to the soil surface one day before sowing. Soluble phosphate at total dose and half of $\mathrm{N}$ and $\mathrm{K}$ of the combinations were applied at corn sowing. The second portion of $\mathrm{N}$ and $\mathrm{K}$ was applied in topdressing 40 days after sowing.

After corn harvest in May 2008, the area was mowed with mechanized mower. The spontaneous remaining vegetation was desiccated with glyphosate-based herbicide using $3 \mathrm{~L} \mathrm{ha}^{-1}$ of the commercial product. Cowpea BRS Guariba cultivar was sown on corn straw in the same plots with manual seeder (matraca) spaced by $0.65 \times 0.20 \mathrm{~m}$, using three seeds per hole.

Plants were collected from an area of $1 \mathrm{~m}^{2}$ of each subplot during flowering for the determination of dry matter and nutrient concentration in the plant. This material was 
dried in an oven with forced air circulation at $60{ }^{\circ} \mathrm{C}$ for 72 hours. Then, weighing was carried out and dry mass value was obtained. After that, some of the material was ground to determine the phosphorus concentration in plant tissue.

Before harvest, pods were collected from eighteen plants of the subplots to determine the number of pods per plant and number of grains per pod. Yield was determined from the pods harvest from the useful area of each subplot at full maturity of grain. The mass of grains was determined after moisture correction to $13 \%$. Analyses were performed according to the Rules for Testing Seeds RTS (Brasil, 2009).

Thus, the evaluated variables were, as follows: yield, number of pods per plant, number of grains per pod, weight of 100 grains, dry weight of the aerial part and phosphorus concentration in the plant.

The results were submitted to analysis of variance, analysis by comparing the residual fertilization of Arad natural phosphate doses and combinations of fertilizers by the Tukey test at 5\% probability. The effect of Arad natural phosphate doses was studied by regression analysis. Statistical analysis was performed using the software SISVAR (Ferreira, 2011).

\section{RESULTS AND DISCUSSION}

Residues of doses of Arad natural phosphate influenced, alone, the number of grains per pod $(\mathrm{GV})$ and the concentration of phosphorus (P) in cowpea plants. A significant increase for all studied variables was found in the residues of fertilizer combinations, except for the content of phosphorus in the plant. No significant effects were found in the interaction of residues of doses of Arad natural phosphate with fertilizer combinations.

Content of phosphorus in the plant (Figure 1A) and the number of grains per pod (Figure 1B) were adjusted to linear regression model, in relation to $\mathrm{P}_{2} \mathrm{O}_{5}$ doses of Arad natural phosphate. The fact that significance was found only for the content of phosphorus in plant tissue and for the number of grains per pod in residues of $\mathrm{P}_{2} \mathrm{O}_{5}$ doses from Arad natural phosphate may be related to a high lack of $\mathrm{P}$ in the soils. In highly weathered soils of humid tropical areas, $\mathrm{P}$ is considered the most limiting nutrient for plant productivity (Novais et al., 2007). According to Freitas et al. (2009), the reactive phosphates exhibit slow and gradual solubilization, providing longer lasting residual effect than soluble phosphates that are adsorbed more rapidly to the soil.

The number of pods per plant (PP) was lower in the treatment that received NPK only (Figure 2A). For the number of grains per pod (GP), NK + limestone and NK treatments were superior to the others (Figure 2B). The mass of 100 grains (M100) was higher in the treatment with
NPK, although it did not differ from the results of the treatment NK + limestone (Figure 2C). Remarkable increases in yield of cowpea in response to phosphate fertilization and the use of limestone and chemical fertilizers were observed in degraded areas of small farmers in the municipality of Irituia, also in the state of Pará (Oliveira \& Galvão, 1999).

Cowpea crop yield showed differences for residues of the combination of applied fertilizers (Figure 3A). Treatments NK + liming and NK were superior to others, producing 1,021 and 1,001 kg ha-1 of cowpea, respectively, and the NK treatment did not differ from the others. This highlights the importance of fertilization and liming at the final crop yield, since when no fertilizer was applied, yield was significantly lower.

The dry matter of the aerial part (DMAP) showed better results in $\mathrm{NK}$ and $\mathrm{NK}+$ limestone treatments, which produced about $100 \mathrm{~kg} \mathrm{ha}^{-1}$ more than the other treatments (Figure 3B). These results demonstrate the beneficial residual effect of liming and natural reactive phosphate for cowpea crop, even when fertilizers were used. The residual effect of fertilizer in the cowpea cultivar BRS-guariba in conventional system was observed by Galvão et al. (2013),
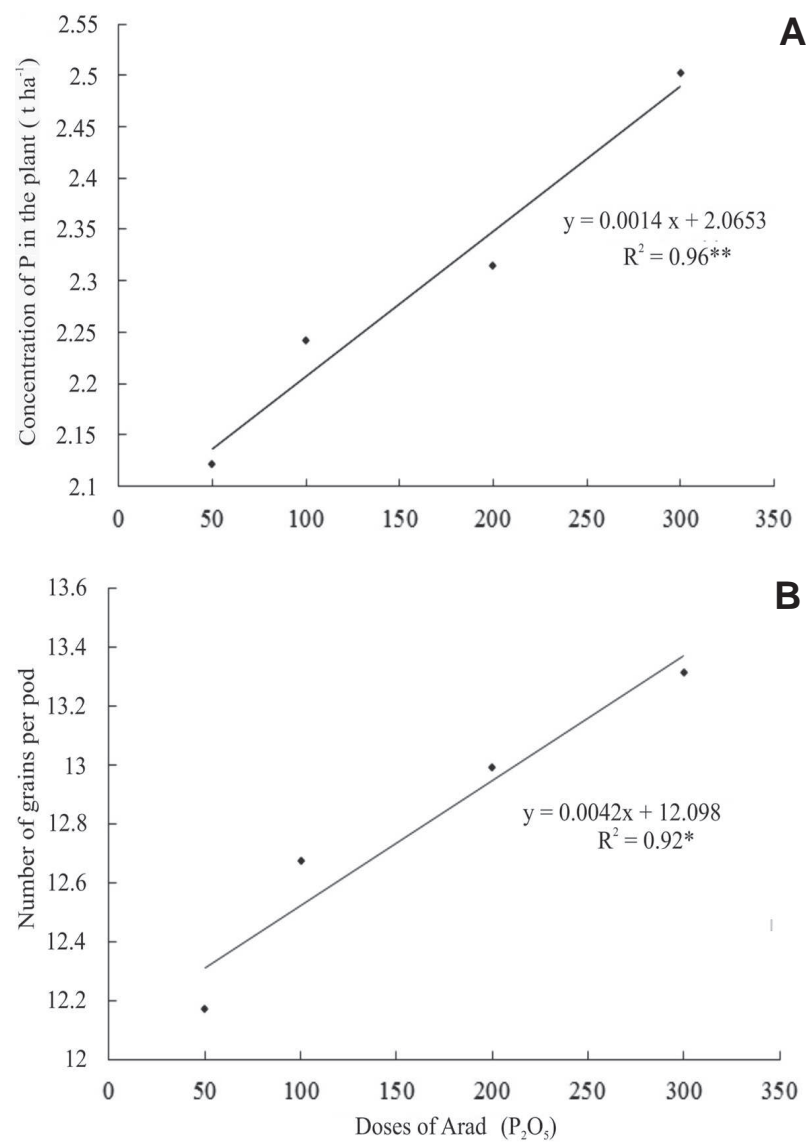

Figure 1: Concentration of phosphorus in the plant (A) and number of grains per pod (B) of cowpea according to the doses of Arad reactive natural phosphorus. *: significant $(\mathrm{P} \leq 0.05)$; $* *$ : significant $(\mathrm{P} \leq 0.01)$ 
whose yield was $1,187 \mathrm{~kg} \mathrm{ha}^{-1}$, larger than that found in this study. These same authors obtained similar results to the results of this work in the production of dry matter of the aerial part $\left(1,500 \mathrm{~kg} \mathrm{ha}^{-1}\right)$.

The residual effect of Arad natural phosphate and fertilizers on $\mathrm{NK}+$ liming treatment provided a yield $30 \%$ higher than the regional average $\left(720 \mathrm{~kg} \mathrm{ha}^{-1}\right)$, suggesting that with the improvement of soil fertility, cowpea crop may present high yield gains. From this, it is inferred that in suitable nutritional conditions, the crop can better express its productive potential, increasing the final production.

The application of rock phosphate has provided relative efficiency of 50 to $55 \%$ when compared to soluble phosphate, for the cowpea yield in the first crop and in the subsequent crop, the residual effect of rock phosphate was equal to soluble phosphate (Maloth \& Presad, 1976).
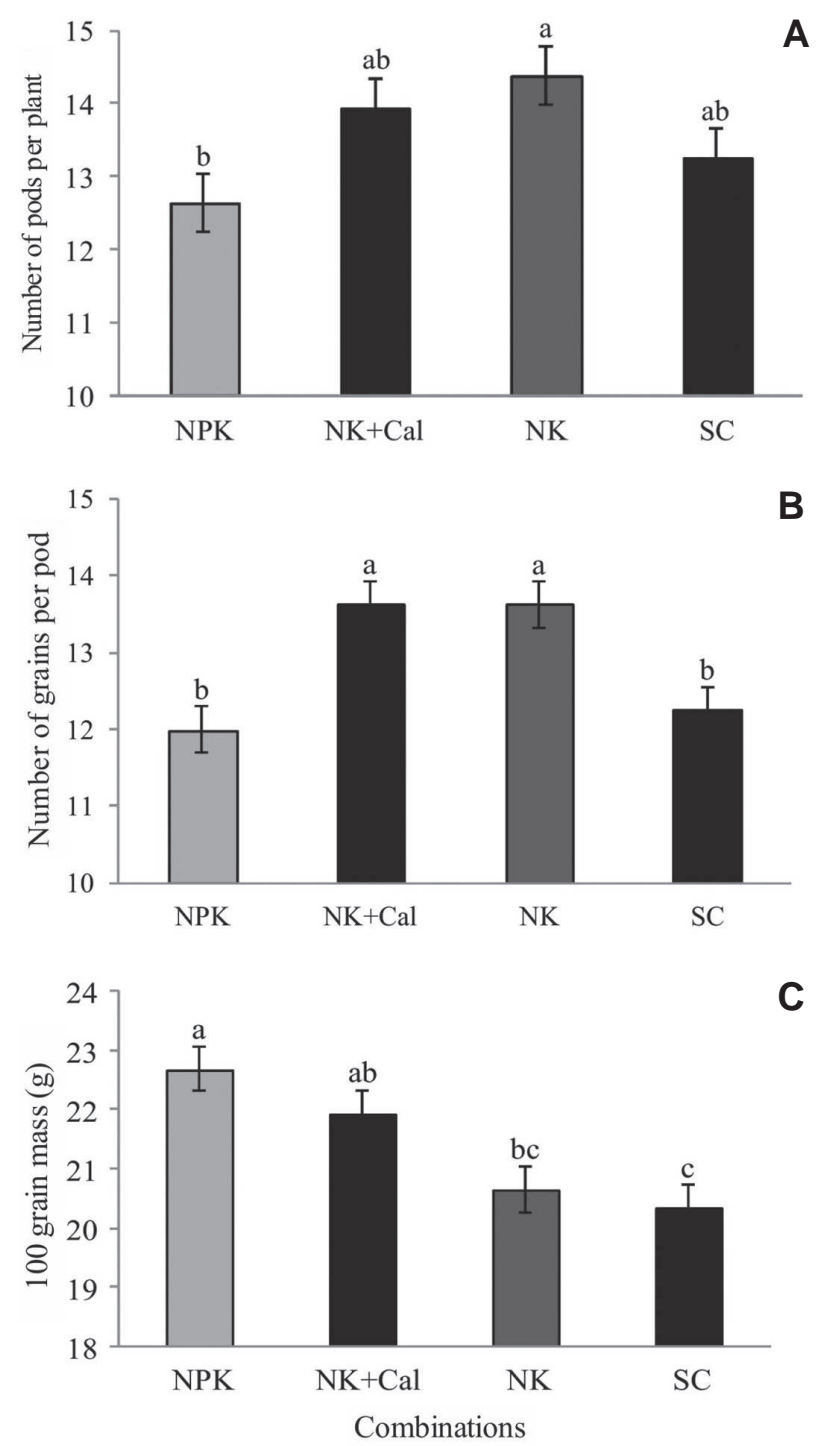

Figure 2: Number of pods per plant (A), number of grains per pod (B) and 100 grains mass (C) of cowpea bean according to the residual effect of combinations with fertilizers.
In this experiment, the residual effects of the use of natural phosphate provided significant gains in the yield of cowpea, indicating good alternative in phosphorus release in succeeding crops in poor fertility areas.

It is noteworthy that natural phosphates, such as Arad natural phosphate, are presented as alternatives to restore the quality of degraded pasture areas in the Amazon, because the solubilization of these materials is slow, which favors greater availability of phosphorus over time (Guedes et al., 2009). This information has environmental and economic importance because these fertilizers are natural and cost much less than industrial phosphates and reduces the risk of contamination.
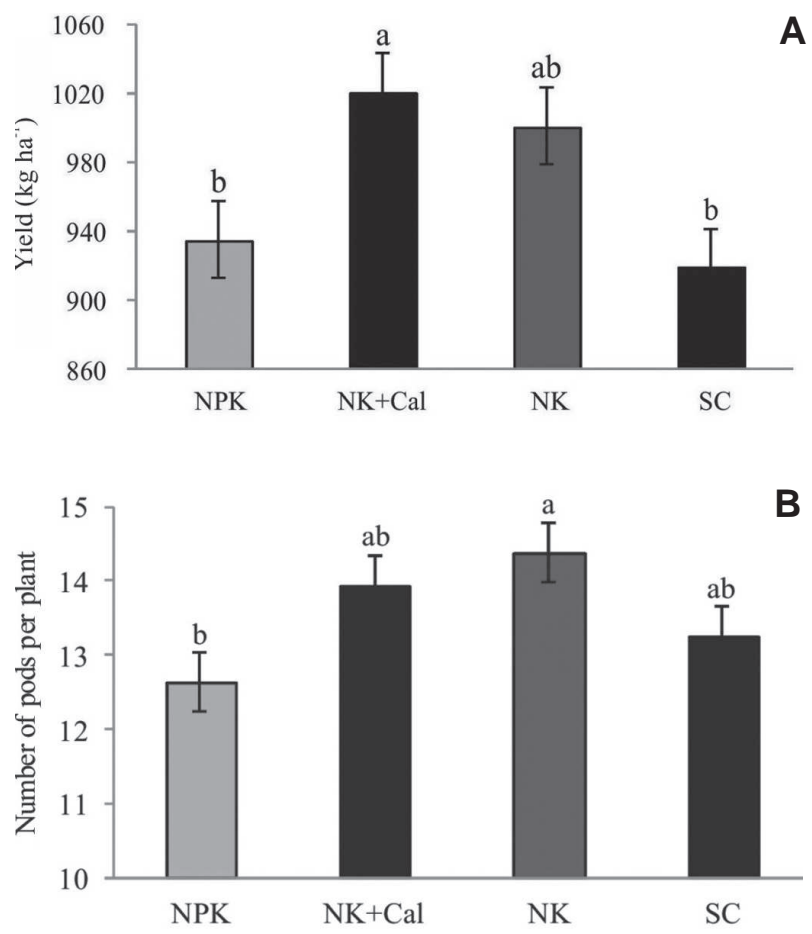

Figure 3: Yield (A) and dry matter of the aerial part (B) of cowpea according to the residual effect of combinations with fertilizers.

\section{CONCLUSIONS}

The residual power of the fertilizer provided cowpea yields higher than the regional average.

The highest yields were obtained when using the NK + limestone and NK fertilizers.

The application of Arad reactive natural phosphate together with NK + limestone increased grain yield when compared to joint application with NPK.

\section{AKNOWLEDGEMENTS}

To Conselho Nacional de Desenvolvimento Científico e Tecnológico - CNPq (National Council for Scientific and Technological Development) for the financial support. 


\section{REFERENCES}

Brasil (2009) Ministério da Agricultura e Reforma Agrária. Regras para análises de sementes. Brasília, SNDA/DNDV/CLAV. 398p.

Carvalho RA, Homma AKH, Conto AJ \& Ferreira CAP (2002) Modificações no sistema de produção de caupi no nordeste paraense. Embrapa/CPATU. 10p. (Documentos).

Costa CFG, Figueiredo RO, Oliveira FA \& Santos IPO (2013) Escoamento superficial em Latossolo Amarelo distrófico típico sob diferentes agroecossistemas no nordeste paraense. Revista Brasileira de Engenharia Agrícola e Ambiental, 17:162169.

Embrapa - Empresa Brasileira de Pesquisa Agropecuária (1997) Manual de Métodos de Análise de Solo. Centro Nacional de Pesquisa de Solos. 2a edição. Rio de Janeiro, Embrapa-CNPS. 212 p.

Embrapa - Empresa Brasileira de Pesquisa Agropecuária (2006) Sistema Brasileiro de Classificação de Solos. Rio de Janeiro, Embrapa-CNPS. 306 p.

Ferreira DF (2011) Sisvar: a computer statistic alanalysis system. Ciência e Agrotecnologia, 35:1039-1042.

Freitas EVS, Nascimento CWA, Goulart DF \& Silva JPS (2009) Disponibilidade de cádmio e chumbo para milho em solo adubado com fertilizantes fosfatados. Revista Brasileira de Ciência do Solo, 33:1899-1907.

Galvão JR, Fernandes AR, Melo NC, Silva VFA \& Albuquerque MPF (2013) Sistemas de manejo e efeito residual do potássio na produtividade e nutrição do feijão-caupi. Revista Caatinga, $26: 41-49$.

Guedes EMS, Fernandes AR, Lima EV, Gama MAP \& Silva ALP (2009) Fosfato natural de Arad e calagem e o crescimento de Brachiaria brizanta em Latossolo Amarelo sob pastagem degradada na Amazônia. Revista de Ciências Agrárias, 52:117129

Maloth S \& Prasad R (1976) Relative efficiency of rock phosphate and superphosphate for cowpea (Vigna unguiculata, L., Walp.) fodder. Plant and Soil, 45:295-300.

Neves Junior AF, Silva AP, Noronha NC \& Cerri CC (2013) Sistemas de manejo do solo na recuperação de uma pastagem degradada em Rondônia. Revista Brasileira de Ciência do Solo, 37:232241

Novais RF, Smyth TJ \& Nunes FN (2007) Elementos requeridos à nutrição de plantas. In: Novais RF, V. Alvarez VH, Barros NF, Fontes RL, Cantarutti RB \& Neves JCL. Fertilidade do solo. Viçosa, Sociedade Brasileira de Ciência do Solo. P. 471-537.

Oliveira RF \& Galvão EUP (1999) Alterações da fertilidade do solo cultivado com milho e caupi submetido à calagem e adubação química, em Irituia - PA. Belém, Embrapa Amazônia Oriental. 26p. (Boletim de Pesquisa, 13).

Secretaria de Agricultura do Pará (2013) Produção de feijão-caupi. Disponível em: 〈http://www.sagri.pa.gov.br〉. Acessado em: 15 de maio de 2015 .

Teixeira IR, Silva GC, Oliveira JPR, Silva AG \& Pelá A (2010) Desempenho agronômico e qualidade de sementes de cultivares de feijão-caupi na região do cerrado. Revista Ciência Agronômica, 41:300-307. 